\title{
Seroepidemiology Study of Cytomegalovirus and Rubella in Pregnant Women in Luanda, Angola: Geospatial Distribution and its Association with Socio-Demographic and Clinical-Obstetric Determinants
}

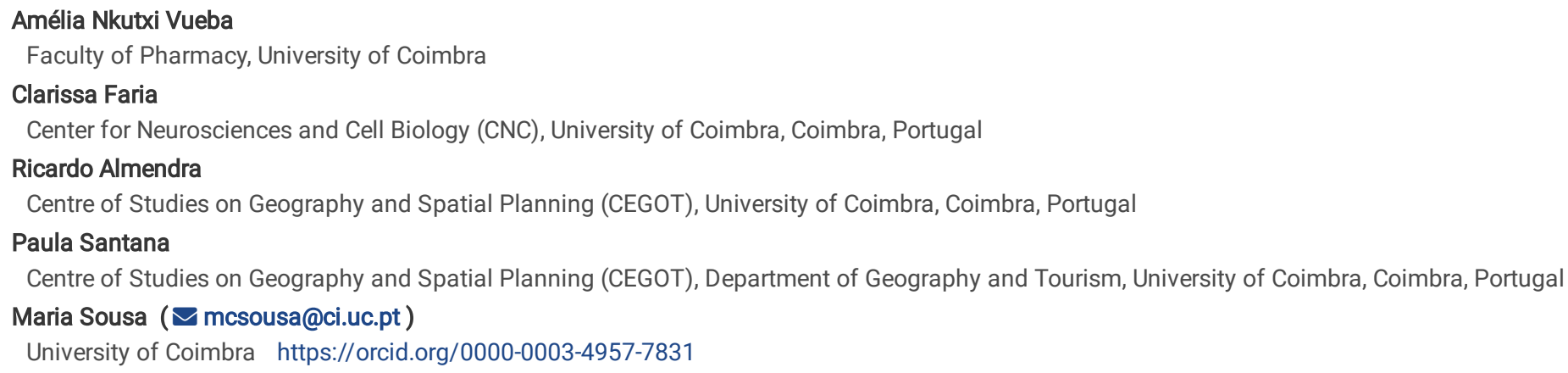

Keywords: Anti-Rubella antibodies, Anti-CMV antibodies, Seroprevalence, Rubella infection, Cytomegalovirus infection, Hepatitis B, HIV, Pregnancy, Miscarriages, Spontaneous Abortion, vaccination

Posted Date: January 28th, 2021

DOI: https://doi.org/10.21203/rs.3.rs-153814/v1

License: @) (i) This work is licensed under a Creative Commons Attribution 4.0 International License. Read Full License

Version of Record: A version of this preprint was published at BMC Infectious Diseases on February 5th, 2022. See the published version at https://doi.org/10.1186/s12879-022-07087-x. 


\section{Abstract}

Background: The main objective was to study the seroprevalence of anti-CMV and anti-Rubella antibodies in pregnant women of Luanda (Angola), identify the primary maternal infection during gestation and to evaluate the socio-demographic risk factors associated with CMV and Rubella virus infections.

Methods: A prospective cross-sectional study was conducted from August 2016 to May 2017. Blood samples were collected and specific anti-CMV and anti-Rubella antibodies (IgG and IgM) were quantified by electrochemiluminescence (COBAS e411). Demographic and clinical data were collected by standardized questionnaire. Bivariate and multivariate logistic regression analysis was used to quantify the effect of clinical and obstetric risk factors on virus seroprevalence. The level of statistical significance was set as $\mathrm{p}<0.05$, and Odds Ratio (OR) and $95 \%$ Confidence Intervals ( $95 \% \mathrm{Cl}$ ) were computed.

Results: The 396 pregnant women participated in the study aged from 15 to 47 . Of the participants, 382 (96.5\%) had anti-CMV IgG antibodies, 8 (2.0\%) had anti-CMV IgG and IgM antibodies and 6 (1.5\%) were seronegative. For Rubella virus, 347 (87.6\%) were positive for anti-lgG, 4 (1.0\%) positive for antiIgG and IgM, and 45 (11.4\%) were seronegative. The mean age of CMV positivity was 28.4 (SD \pm 6.2 ) and for Rubella virus was 28.6 (SD \pm 6.1 ). The multivariate logistic regression analysis has shown a significant association between Rubella virus infection and pregnant women without child (OR 2.673; Cl: 1.026 - 7.007) and suffering spontaneous abortion (OR 3.232; Cl: 1.192 - 7.952). In contrast, the level of schooling, residence, occupation, marital status, number of children in the household, basic sanitation, gestational age, history of miscarriages and hepatitis B were not significantly associated with the Rubella virus infection.

Conclusions: Overall, this study showed that there is a high seroprevalence of anti-CMV and anti-Rubella antibodies in pregnant women in Luanda. Therefore, it is important a rapid and accurate diagnosis of CMV and Rubella infection in pregnant women to prevent congenital infections. Rubella vaccination should be offered to women non-immune to Rubella. Overall, it would be important to implement national screening for CMV, Rubella and other diseases linked to maternal and child health.

\section{Background}

Several infections caused by microorganisms can be transmitted to the fetus during pregnancy, causing fetal death or sequelae to the newborn: Toxoplasmosis, Other (syphilis, varicella-zoster, parvovirus B19), Rubella, Cytomegalovirus (CMV) and Herpes infections as known by TORCH infections [1]. The agents of the TORCH infections, lead to the development of a maternal infection and can pass in the uterine circulation at any gestational age [1] On the other hand, the infection can lead to spontaneous abortions, sterility, congenital malformations and intrauterine fetal loss. Prenatal surveillance is important for the prevention of vertical transmission.

The Angolan National Health Development Plan (2012-2025) does not include the control of diseases such as Rubella and Cytomegalovirus. The absence of early diagnosis and the consequent lack of treatment of maternal infections can considerably increase the rates of perinatal morbidity and mortality.

CMV or Herpesvirus 5 is a member of the Herpesviridae family, being the largest virus [2]. Man is the only reservoir for CMV and the virus transmission occurs after direct or indirect contact with saliva, oropharyngeal secretions, endocervical secretions, urine, sperm, breast milk, tears, blood products or organs, and by vertical transmission [3]. However, CMV infection is less contagious than that of other members of the same family of Varicella Zoster Virus [2]. The main infected cells are the endothelial cells and the leukocytes, and then the hematogenous propagation is carried out in the organism. Like the other members of the Herpesviridae family, CMV arrest in body (latent phase) after a primary infection. The acquired immunity is not completely protective and secondary infections may occur during the latent phase [4]. The pregnant women are contaminated by patients who excrete large numbers of viruses, including children, immunosuppressed patients and transplanted patients. Vertical transmission is transplacental hematogenous and occurs during maternal viraemia. The transmission rate varies with the type of maternal infection: between 30 and $50 \%$ on primary infections and 0.1 and $3 \%$ on secondary infections (re-infections or reactivations of a latent infection) [2, 4]. The gestational age may also play an important role in the vertical transmission rate, increasing with gestational age: $36 \%$ in the first trimester, $44 \%$ in the second and $77.6 \%$ in the last trimester. However, the consequences of CMV infection are more severe when maternal infection occurs before 20 weeks $[2,4]$. Also, CMV is considered a common opportunistic infection among individuals infected with the human immunodeficiency virus (HIV), a major source of serious viral complications among organ transplant recipients and a major cause of hearing loss, vision loss and mental retardation in children with congenital infection [5].

Rubella is caused by a virus of the Togaviridae family and genus Rubivirus. The most common form of virus transmission is through direct contact with respiratory secretions droplets of infected persons [6]. It is a benign disease characterized by a macular rash accompanied by low fever, joint pain, pharyngitis and cervical adenopathies [6], however, it becomes severe to fetus when it occurs during pregnancy [7]. The teratogenic properties of the rubella virus were first discovered in Australia in 1941 by Gregg who associated the occurrence of rubella during pregnancy with the presence of congenital cataracts [8]. Maternal infection with the rubella virus during the first trimester is often associated with fetal death, miscarriage or adverse neonatal outcome, including heart problems, cataracts and deafness, known as congenital rubella syndrome (CRS), which has a higher neonatal morbidity [9]. This severity of fetal infection is related to the period of organogenesis, due to the high virus tropism for fetal tissues [10]. Some defects were later reported as consequence of maternal infections in the second trimester [9]. In order to avoid vertical transmission, seronegative women should be detected during the preconception period and their pregnancies be planned after immunization [11].

In Angola, there are no reports of CMV and Rubella studies. Therefore, the main objective of this work was to study the seroprevalence of anti-CMV and anti-Rubella antibodies in pregnant women attending at Lucrécia Paim Maternity Hospital (LPMH) of Luanda and to provide a detailed analysis of the 
geographical distribution. In addition, we aimed to identify the maternal infection and to evaluate the risk factors associated with CMV and Rubella infection.

\section{Methods \\ Ethical Considerations}

The present study has been approved by the Research Ethics Committee of LPMH through the National Institute of Public Health of the Republic of Angola (n³01019) (S1 File).

Participant individuals provided a written signed informed consent prior to sample collection and for participants younger than 18 years, informed consent was provided by parents or guardians after a detailed explanation of the objectives of the work.

\section{Study Population}

The study population was constituted by pregnant women monitored for routine prenatal assessment at LPMH, a reference maternity in Angola, located in Luanda. The referred maternity is a tertiary-level public health institution specialized in maternal and child health care, teaching and research. The health institution offers outpatient and inpatient services, has 400 beds for hospitalization video laparoscopy, hysteroscopy, milk bank, pathological anatomy, assisted reproductive services, genetics and mammography. Consequently, the women attended in the LPMH come from all over the country, however mainly from Luanda, the capital of Angola.

The study included women aged from 15 to 47 years, who had a pregnancy proven by ultrasonography and laboratory tests. For the obstetric follow-up we counted on the collaboration of the medical and nursing team of the department of obstetrics of the LPMH.

\section{Sociodemographic, clinical and housing characteristics of the pregnant women}

A standardized questionnaires in face-to-face interviews were used to obtain the socio-demographic, clinical, and housing characteristics from the pregnant women (S2 File). Socio-demographic items included age, residence, occupation, schooling level, and socio-economic status. Clinical characteristics included gestation age, number of pregnancies, history of abortion, the frequency of miscarriages, child born premature, number of children with disabilities and with mental retardation, presence of any underlying disease, long-term fever, history of hepatitis B and HIV. The housing characteristics like type of flooring, destination of faeces, the number of children in the household and crowding were also inclued. The questionnaire was written in Portuguese, the official language in the Republic of Angola, developed and revised accordingly.

\section{Blood Sample Collection and Laboratory Procedures}

A cross-sectional study was conducted from August 2016 to May 2017 and a total of 396 pregnant women were included in the survey.

Blood samples was collected and serum samples were obtained after centrifugation. These samples were immediately transferred (properly packaged in dry ice) to the Clinical Pathology Service of Clínica Sagrada Esperança (Luanda) and kept at $-80{ }^{\circ} \mathrm{C}$ until serological analysis.

The quantification of anti-CMV and anti-Rubella IgG and IgM antibodies was done by Electrochemiluminescence (ECL) using commercially available kits for COBAS e411 (Roche, Sistemas de Diagnósticos Lda), according to the guidelines of the manufacturer. The anti-CMV IgG and IgM levels were expressed as IU/mL and COI (Cut-off index), respectively: values $<0.5 \mathrm{IU} / \mathrm{mL}$ of anti-CMV IgG antibody are considered negative and values $\geq 1.0 \mathrm{IU} / \mathrm{mL}$ are considered positive; values $<0.7 \mathrm{COI}$ of anti-CMV IgM antibody are considered negative and values $\geq 1.0$ are considered positive.

The anti-Rubella IgG and IgM levels were expressed as IU/mL and COI, respectively: values $<10.0 \mathrm{IU} / \mathrm{mL}$ of anti-Rubella IgG antibody are considered negative and values $\geq 10.0 \mathrm{IU} / \mathrm{mL}$ are considered positive; values $<0,8 \mathrm{CO}$ of anti-Rubella IgM antibody are considered negative and values $\geq 1.0$ are considered positive.

\section{Geospatial analysis}

The address of pregnant women was collected during the interview allowing the identification of the residence place. This information was converted into geographic coordinates (latitude and longitude) through the www.google.pt/maps/. The spatial distribution of pregnant women was assessed through a Kernel Density Function that allowed the estimation of the intensity of events across a surface.

\section{Stastical Analysis}

The data entry was carried out using Excel software and analysed using Statistical Package for the Social Sciences (SPSS) version 20. The exploratory analysis of the categorical variables and quantitative variables are presented as percentages (mean \pm SD). Bivariate and multivariate logistic regression were developed to assess the effect of different risk factors on rubella virus seroprevalence. The level of statistical significance was set as $p<0.05$, and Odds Ratio (OR) and 95\% Confidence Intervals (95\% Cl) were computed.

\section{Results}

Between August 2016 and May 2017, a total of 396 pregnant women were tested for anti-CMV and anti-Rubella antibodies. The distribution of IgG and/or IgM antibodies to CMV and rubella of seropositive and seronegative pregnant women is summarized in Table 1. The majority of women had previous 
exposure to the CMV virus: 382 (96.5\%) were positive for anti-CMV IgG; 8 (2.0\%) were positive for anti-CMV IgM and IgG; and 6 (1.5\%) were seronegative for anti-CMV antibodies. For Rubella virus, 347 (87.6\%) were positive for anti-Rubella IgG, 4 (1.0\%) were positive for anti-Rubella IgM and IgG and 45 (11.4\%) were seronegative (Table 1). Although the majority of women are immune to rubella virus, a significant number are susceptible to the primary infection.

Table 1

Profile of antibodies IgG and IgM anti-CMV and anti-Rubella virus on pregnant women from Luanda (Angola).

\begin{tabular}{|c|c|c|c|}
\hline Immune response & Number & Percentage (\%) & Interpretation \\
\hline \multicolumn{4}{|l|}{ Anti-CMV } \\
\hline $\lg \mathrm{G}(+) \lg M(-)$ & 382 & 96.5 & Previous Exposure \\
\hline $\lg G(+) \lg M(+)$ & 8 & 2.0 & Active (Primary/Latent) infection \\
\hline $\lg G(-) \lg M(-)$ & 6 & 1.6 & Susceptible to primary infection \\
\hline $\lg G(-) \lg M(+)$ & $0-$ & $0-$ & Recent primary infection \\
\hline Total positive & 390 & 98.5 & Overall prevalence \\
\hline Total negative & 6 & 1.5 & Overall prevalence \\
\hline \multicolumn{4}{|l|}{ Anti-Rubella } \\
\hline $\lg G(+) \lg M(-)$ & 347 & 87.6 & Immune \\
\hline $\lg G(+) \lg M(+)$ & 4 & 1.0 & Active (Primary/Latent) infection \\
\hline $\lg G(-) \lg M(-)$ & 45 & 11.4 & Susceptible (to primary infection) \\
\hline $\lg G(-) \lg M(+)$ & 0 & 0 & Recent primary infection \\
\hline Total positive & 351 & 88.6 & Overall prevalence \\
\hline Total negative & 45 & 11.4 & Overall prevalence \\
\hline
\end{tabular}

The characteristics of the individual pregnant women and details on home conditions and food habits were collected using a structured questionnaire (S3 File).

The ages of the pregnant women ranged from 15 to 47 years with an average of $28.4 \pm 6.2$ (Mean \pm SD); pregnant women between 26 and 35 years were the majority of participants $(n=207)$ (Table 2$)$. Regarding education level, $3(0.8 \%)$ are illiterate, $149(37.6)$ have basic education, $200(50.5 \%)$ have a high school education and $44(11.1 \%)$ have higher education. In relation to residence, $180(45.5 \%)$ live in the municipality of Luanda, 87 (22.0\%) in the municipality of Belas, 86 (21.7\%) in the municipality of Viana, 29 (7.3\%) in the municipality of Cazenga and 14 (3.5\%) in the municipality of Cacuaco. Regarding occupancy, 150 (37.9\%) women work on public administration services, 64 (16.2\%) are students, 63 (15.9\%) are domestic, 49 (12,4\%) are street vendors, 39 (9.8\%) are store employees and 31 (7.8\%) work in the catering area. The majority of pregnant women (270; 68.2\%), are single and 126 (31.8\%) are married. The mean of gestational age was $14.5 \pm 6.8$ (Mean \pm SD) weeks and $63.9 \%$ of the pregnant women had more than one children (with mean birth rate of $1.8 \pm 0.7($ Mean $\pm S D))$. 
Sociodemographic characteristics of seropositive and seronegative pregnant women to CMV and Rubella virus and respective prevalences.

\begin{tabular}{|c|c|c|c|c|c|c|c|c|c|}
\hline \multirow[t]{2}{*}{ Characteristics } & \multicolumn{4}{|l|}{ CMV } & \multicolumn{4}{|c|}{ Rubella vírus } & \multirow[t]{2}{*}{ Total } \\
\hline & $\begin{array}{l}\text { Positive } \\
\text { n (\%) }\end{array}$ & $\begin{array}{l}\text { Seroprevalence } \\
\text { (\%) }\end{array}$ & $\begin{array}{l}\text { Negative } \\
\text { n (\%) }\end{array}$ & $\begin{array}{l}\text { Seroprevalence } \\
(\%)\end{array}$ & $\begin{array}{l}\text { Positive } \\
\text { n (\%) }\end{array}$ & $\begin{array}{l}\text { Seroprevalence } \\
(\%)\end{array}$ & $\begin{array}{l}\text { Negative } \\
\text { n (\%) }\end{array}$ & $\begin{array}{l}\text { Seroprevalence } \\
(\%)\end{array}$ & \\
\hline \multicolumn{10}{|l|}{$\begin{array}{l}\text { Age group } \\
\text { (years) }\end{array}$} \\
\hline$\leq 19$ & $23(5.9)$ & 100.0 & $0(00.0)$ & $0(00.0)$ & $18(5.1)$ & 78.3 & 5 (11.1) & 21.7 & $23(5.8)$ \\
\hline $20-25$ & $\begin{array}{l}110 \\
(28.2)\end{array}$ & 99.1 & 1 (16.7) & 0.9 & $\begin{array}{l}97 \\
(27.6)\end{array}$ & 87.4 & $\begin{array}{l}14 \\
(31.1)\end{array}$ & 12.6 & 111(28.0) \\
\hline $26-35$ & $\begin{array}{l}202 \\
(51.8)\end{array}$ & 97.6 & $5(83.3)$ & 2.4 & $\begin{array}{l}185 \\
(52.7)\end{array}$ & 89.4 & $\begin{array}{l}22 \\
(48.9)\end{array}$ & 10.6 & 207(52.3) \\
\hline $36-47$ & $\begin{array}{l}55 \\
(14.1)\end{array}$ & 100.0 & $0(00.0)$ & $0(00.0)$ & $\begin{array}{l}51 \\
(14.6)\end{array}$ & 92.7 & $4(8.9)$ & 7.3 & 55 (13.9) \\
\hline \multicolumn{10}{|l|}{ Education } \\
\hline Illiterate & $3(0.8)$ & 100.0 & $0(00.0)$ & & $3(0.9)$ & 100.0 & $0(00.0)$ & $0(00.0)$ & $3(0.8)$ \\
\hline $\begin{array}{l}\text { Elementary } \\
\text { School }\end{array}$ & $\begin{array}{l}148 \\
(37.9)\end{array}$ & 99.3 & 1 (16.6) & 0.7 & $\begin{array}{l}136 \\
(38.7)\end{array}$ & 91.3 & $\begin{array}{l}13 \\
(28.9)\end{array}$ & 8.7 & $\begin{array}{l}149 \\
(37.6)\end{array}$ \\
\hline High school & $\begin{array}{l}196 \\
(50.3)\end{array}$ & 98.0 & $4(66.7)$ & 2.0 & $\begin{array}{l}172 \\
(49.0)\end{array}$ & 86.0 & $\begin{array}{l}28 \\
(62.2)\end{array}$ & 14.0 & $\begin{array}{l}200 \\
(50.5)\end{array}$ \\
\hline $\begin{array}{l}\text { Higher } \\
\text { education }\end{array}$ & $\begin{array}{l}43 \\
(11.0)\end{array}$ & 97.3 & $1(16.7)$ & 2.7 & $\begin{array}{l}40 \\
(11.4)\end{array}$ & 90.9 & $4(8.9)$ & 9.1 & 44 (11.1) \\
\hline \multicolumn{10}{|l|}{ Residence } \\
\hline Belas & $\begin{array}{l}85 \\
(21.8)\end{array}$ & 97.7 & $2(33.3)$ & 2.3 & $\begin{array}{l}76 \\
(21.7)\end{array}$ & 87.4 & $\begin{array}{l}11 \\
(24.2)\end{array}$ & 12.6 & $87(22.0)$ \\
\hline Cacuaco & $13(3.3)$ & 92.9 & $1(16.7)$ & 7.1 & $13(3.7)$ & 92.9 & $1(2.2)$ & 7.1 & $14(3.5)$ \\
\hline Viana & $\begin{array}{l}85 \\
(21.8)\end{array}$ & 98.8 & $1(16.7)$ & 1.2 & $\begin{array}{l}76 \\
(21.7)\end{array}$ & 88.4 & $\begin{array}{l}10 \\
(22.2)\end{array}$ & 11.6 & $86(21.7)$ \\
\hline Cazenga & $29(7.5)$ & 100.0 & $0(00.0)$ & 0.0 & $25(7.1)$ & 86.2 & $4(9.0)$ & 13.8 & $29(7.3)$ \\
\hline Launda & $\begin{array}{l}178 \\
(45.6)\end{array}$ & 98.9 & $2(33.3)$ & 1.1 & $\begin{array}{l}161 \\
(45.8)\end{array}$ & 89.4 & $\begin{array}{l}19 \\
(42.2)\end{array}$ & 10.6 & $\begin{array}{l}180 \\
(45.5)\end{array}$ \\
\hline \multicolumn{10}{|l|}{ Employment } \\
\hline Homemakers & $\begin{array}{l}62 \\
(15.9)\end{array}$ & 98.4 & 1 (16.7) & 1.6 & $\begin{array}{l}57 \\
(16.2)\end{array}$ & 90.5 & $6(13.3)$ & 9.5 & $63(15.9)$ \\
\hline $\begin{array}{l}\text { Public } \\
\text { administration } \\
\text { service }\end{array}$ & $\begin{array}{l}147 \\
(37.7)\end{array}$ & 98.0 & $3(50.0)$ & 2.0 & $\begin{array}{l}131 \\
(37.3)\end{array}$ & 87.3 & $\begin{array}{l}19 \\
(42.2)\end{array}$ & 12.7 & $\begin{array}{l}150 \\
(37.9)\end{array}$ \\
\hline Student & $\begin{array}{l}62 \\
(15.9)\end{array}$ & 96.9 & $2(33.3)$ & 3.1 & $\begin{array}{l}56 \\
(16.0)\end{array}$ & 87.5 & $8(17.8)$ & 12.5 & $64(16.2)$ \\
\hline $\begin{array}{l}\text { Restaurant } \\
\text { waitress }\end{array}$ & $31(7.9)$ & 100.0 & $0(00.0)$ & $0(00.0)$ & $26(7.4)$ & 83.9 & $5(11.1)$ & 16.1 & $31(7.8)$ \\
\hline Street vendor & $\begin{array}{l}49 \\
(12.6)\end{array}$ & 100.0 & $0(00.0)$ & $0(00.0)$ & $\begin{array}{l}45 \\
(12.8)\end{array}$ & 91.8 & $4(8.9)$ & 8.2 & 49 (12.4) \\
\hline $\begin{array}{l}\text { Shop } \\
\text { assistants }\end{array}$ & $\begin{array}{l}39 \\
(10.0)\end{array}$ & 100.0 & $0(00.0)$ & $0(00.0)$ & $\begin{array}{l}36 \\
(10.3)\end{array}$ & 92.3 & $3(6.7)$ & 7.7 & $39(9.8)$ \\
\hline \multicolumn{10}{|l|}{ Marital status } \\
\hline Married & $\begin{array}{l}126 \\
(32.3)\end{array}$ & 100.0 & $0(00.0)$ & $0(00.0)$ & $\begin{array}{l}110 \\
(31.3)\end{array}$ & 87.3 & $\begin{array}{l}16 \\
(35.6)\end{array}$ & 12.7 & $\begin{array}{l}126 \\
(31.8)\end{array}$ \\
\hline Single & $\begin{array}{l}264 \\
(67.7)\end{array}$ & 97.8 & $\begin{array}{l}6 \\
(100.0)\end{array}$ & 2.2 & $\begin{array}{l}241 \\
(68.7)\end{array}$ & 89.3 & $\begin{array}{l}29 \\
(64.4)\end{array}$ & 10.7 & $\begin{array}{l}270 \\
(68.2)\end{array}$ \\
\hline \multicolumn{10}{|l|}{$\begin{array}{l}\text { Gestational } \\
\text { age }\end{array}$} \\
\hline 1st Trimester & $\begin{array}{l}199 \\
(51.0)\end{array}$ & 98.5 & $3(50.0)$ & 1.5 & $\begin{array}{l}181 \\
(51.6)\end{array}$ & 89.6 & $\begin{array}{l}21 \\
(46.7)\end{array}$ & 10.4 & $\begin{array}{l}202 \\
(51.0)\end{array}$ \\
\hline
\end{tabular}




\begin{tabular}{|c|c|c|c|c|c|c|c|c|c|}
\hline \multirow[t]{2}{*}{ Characteristics } & \multicolumn{4}{|l|}{ CMV } & \multicolumn{4}{|c|}{ Rubella vírus } & \multirow[t]{2}{*}{ Total } \\
\hline & $\begin{array}{l}\text { Positive } \\
\text { n (\%) }\end{array}$ & $\begin{array}{l}\text { Seroprevalence } \\
(\%)\end{array}$ & $\begin{array}{l}\text { Negative } \\
\mathrm{n}(\%)\end{array}$ & $\begin{array}{l}\text { Seroprevalence } \\
\text { (\%) }\end{array}$ & $\begin{array}{l}\text { Positive } \\
\text { n (\%) }\end{array}$ & $\begin{array}{l}\text { Seroprevalence } \\
\text { (\%) }\end{array}$ & $\begin{array}{l}\text { Negative } \\
\text { n (\%) }\end{array}$ & $\begin{array}{l}\text { Seroprevalence } \\
\text { (\%) }\end{array}$ & \\
\hline 2nd Trimester & $\begin{array}{l}152 \\
(39.0)\end{array}$ & 98.1 & $3(50.0)$ & 1.9 & $\begin{array}{l}135 \\
(38.4)\end{array}$ & 87.1 & $\begin{array}{l}20 \\
(44.4)\end{array}$ & 12.9 & $\begin{array}{l}155 \\
(39.1)\end{array}$ \\
\hline 3rd Trimester & $\begin{array}{l}39 \\
(10.0)\end{array}$ & 100.0 & $0(00.0)$ & $0(00.0)$ & $\begin{array}{l}35 \\
(10.0)\end{array}$ & 89.7 & $4(8.9)$ & 10.3 & 39 (9.9) \\
\hline \multicolumn{10}{|l|}{$\begin{array}{l}\text { Number of } \\
\text { births }\end{array}$} \\
\hline 0 & $\begin{array}{l}84 \\
(21.5)\end{array}$ & 97.7 & $2(33.3)$ & 2.3 & $\begin{array}{l}71 \\
(20.2)\end{array}$ & 82.6 & $\begin{array}{l}15 \\
(33.3)\end{array}$ & 17.4 & $86(21.7)$ \\
\hline 1 & $\begin{array}{l}118 \\
(30.3)\end{array}$ & 99.2 & $1(16.7)$ & 0.8 & $\begin{array}{l}103 \\
(29.3)\end{array}$ & 86.6 & $\begin{array}{l}16 \\
(35.5)\end{array}$ & 13.4 & $\begin{array}{l}119 \\
(30.0)\end{array}$ \\
\hline 66 (16.9) & 97.1 & $2(33.3)$ & 2.9 & $61(17.4)$ & 89.7 & $7(15.6)$ & 10.3 & 68 (17.2) & \\
\hline$\geq 3$ & $\begin{array}{l}122 \\
(31.3)\end{array}$ & 99.2 & $1(16.7)$ & 0.8 & $\begin{array}{l}116 \\
(33.1)\end{array}$ & 94.3 & $7(15.6)$ & 5.7 & $\begin{array}{l}123 \\
(31.1)\end{array}$ \\
\hline \multicolumn{10}{|l|}{$\begin{array}{l}\text { Spontaneous } \\
\text { abortion }\end{array}$} \\
\hline Yes & 27 (6.9) & 100.0 & $0(00.0)$ & $0(00.0)$ & $20(5.7)$ & 74.1 & $7(15.6)$ & 25.9 & $27(6.8)$ \\
\hline No & $\begin{array}{l}363 \\
(93.1)\end{array}$ & 98.4 & $\begin{array}{l}6 \\
(100.0)\end{array}$ & 1.6 & $\begin{array}{l}331 \\
(94.3)\end{array}$ & 89.7 & $\begin{array}{l}38 \\
(84.4)\end{array}$ & 10.3 & $\begin{array}{l}369 \\
(93.2)\end{array}$ \\
\hline \multicolumn{10}{|l|}{$\begin{array}{l}\text { History of } \\
\text { miscarriages }\end{array}$} \\
\hline No & $\begin{array}{l}219 \\
(56.2)\end{array}$ & 98.2 & $4(66.7)$ & 1.8 & $\begin{array}{l}190 \\
(54.1)\end{array}$ & 73.2 & $\begin{array}{l}33 \\
(73.3)\end{array}$ & 26.8 & $\begin{array}{l}223 \\
(56.3)\end{array}$ \\
\hline Yes & $\begin{array}{l}171 \\
(43.8)\end{array}$ & 98.8 & $2(33.3)$ & 1.2 & $\begin{array}{l}161 \\
(45.9)\end{array}$ & 93.1 & $\begin{array}{l}12 \\
(26.7)\end{array}$ & 6.9 & $\begin{array}{l}173 \\
(43.7)\end{array}$ \\
\hline \multicolumn{10}{|l|}{$\begin{array}{l}\text { Children at } \\
\text { home }\end{array}$} \\
\hline Yes & $\begin{array}{l}386 \\
(99.0)\end{array}$ & 98.5 & $6(100)$ & 1.5 & $\begin{array}{l}348 \\
(99.1)\end{array}$ & 88.8 & $\begin{array}{l}44 \\
(97.8)\end{array}$ & 11.2 & $\begin{array}{l}392 \\
(99.0)\end{array}$ \\
\hline No & $4(1.0)$ & 100.0 & $0(00.0)$ & $0(00.0)$ & $3(0.9)$ & 75.0 & $1(2.2)$ & 25.0 & $4(1.0)$ \\
\hline \multicolumn{10}{|l|}{$\begin{array}{l}\text { Number of } \\
\text { children in the } \\
\text { household }\end{array}$} \\
\hline 0 & $4(1.0)$ & 100.0 & $0(00.0)$ & $0(00.0)$ & $3(0.9)$ & 75.0 & $1(2.2)$ & 25.0 & $4(1.0)$ \\
\hline 1 & $\begin{array}{l}137 \\
(35.1)\end{array}$ & 98.6 & $2(33.3)$ & 1.4 & $\begin{array}{l}118 \\
(33.6)\end{array}$ & 84.9 & $\begin{array}{l}21 \\
(46.7)\end{array}$ & 15.1 & $\begin{array}{l}139 \\
(35.1)\end{array}$ \\
\hline 2 & $\begin{array}{l}152 \\
(39.0)\end{array}$ & 98.1 & $3(50.0)$ & 1.9 & $\begin{array}{l}141 \\
(40.2)\end{array}$ & 91.0 & $\begin{array}{l}14 \\
(31.1)\end{array}$ & 9.0 & $\begin{array}{l}155 \\
(39.1)\end{array}$ \\
\hline$\geq 3$ & $\begin{array}{l}97 \\
(24.9)\end{array}$ & 99.0 & $1(16.7)$ & 1.0 & $\begin{array}{l}89 \\
(25.3)\end{array}$ & 90.8 & $9(20.0)$ & 9.2 & $98(24.8)$ \\
\hline \multicolumn{10}{|l|}{$\begin{array}{l}\text { Hepatitis B } \\
\text { infection }\end{array}$} \\
\hline No & $\begin{array}{l}265 \\
(67.9)\end{array}$ & 98.5 & $4(66.7)$ & 1.5 & $\begin{array}{l}237 \\
(67.5)\end{array}$ & 88.1 & $\begin{array}{l}32 \\
(71.1)\end{array}$ & 11.9 & $\begin{array}{l}269 \\
(67.9)\end{array}$ \\
\hline Yes & $\begin{array}{l}125 \\
(32.1)\end{array}$ & 98.4 & 2 (33.3) & 1.6 & $\begin{array}{l}114 \\
(32.5)\end{array}$ & 89.8 & $\begin{array}{l}13 \\
(28.9)\end{array}$ & 10.2 & $\begin{array}{l}127 \\
(32.1)\end{array}$ \\
\hline \multicolumn{10}{|l|}{ HIV status } \\
\hline No & $\begin{array}{l}332 \\
(85.1)\end{array}$ & 98.5 & 5 (83.3) & 1.5 & $\begin{array}{l}294 \\
(83.8)\end{array}$ & 87.2 & $\begin{array}{l}43 \\
(95.6)\end{array}$ & 12.8 & $\begin{array}{l}337 \\
(85.1)\end{array}$ \\
\hline Yes & $\begin{array}{l}58 \\
(14.9)\end{array}$ & 98.3 & $1(16.7)$ & 1.7 & $\begin{array}{l}57 \\
(16.2)\end{array}$ & 96.6 & $2(4.4)$ & 3.4 & 59 (14.9) \\
\hline
\end{tabular}




\begin{tabular}{|c|c|c|c|c|c|c|c|c|c|}
\hline \multirow[t]{3}{*}{ Characteristics } & \multicolumn{4}{|l|}{ CMV } & \multicolumn{4}{|c|}{ Rubella vírus } & \multirow[t]{3}{*}{ Total } \\
\hline & Positive & Seroprevalence & Negative & Seroprevalence & Positive & Seroprevalence & Negative & Seroprevalence & \\
\hline & $n(\%)$ & (\%) & $\mathrm{n}(\%)$ & (\%) & $n(\%)$ & (\%) & n (\%) & (\%) & \\
\hline \multicolumn{10}{|l|}{$\begin{array}{l}\text { Awareness of } \\
\text { CMV and } \\
\text { Rubella }\end{array}$} \\
\hline $\begin{array}{l}\text { Does not know } \\
\text { anything } \\
\text { about the } \\
\text { disease }\end{array}$ & $\begin{array}{l}351 \\
(90.0)\end{array}$ & 98.9 & $4(66.7)$ & 1.1 & $\begin{array}{l}314 \\
(89.5)\end{array}$ & 88.5 & $\begin{array}{l}41 \\
(91.1)\end{array}$ & 11.5 & $\begin{array}{l}355 \\
(89.6)\end{array}$ \\
\hline $\begin{array}{l}\text { Heard speak, } \\
\text { but do not } \\
\text { know anything } \\
\text { about it }\end{array}$ & $34(8.7)$ & 94.4 & $2(33.3)$ & 5.6 & $33(9.4)$ & 91.7 & $3(6.7)$ & 8.3 & $36(9.1)$ \\
\hline $\begin{array}{l}\text { Know } \\
\text { anything } \\
\text { about the } \\
\text { disease }\end{array}$ & $5(1.3)$ & 100.0 & $0(00.0)$ & $0(00.0)$ & $4(1.1)$ & 80.0 & $1(2.2)$ & 20.0 & $5(1.3)$ \\
\hline \multicolumn{10}{|l|}{$\begin{array}{l}\text { Pre-natal } \\
\text { consultation } \\
\text { was } \\
\text { performed in } \\
\text { all } \\
\text { pregnancies }\end{array}$} \\
\hline Yes & $\begin{array}{l}381 \\
(97.7)\end{array}$ & 98.4 & $\begin{array}{l}6 \\
(100.0)\end{array}$ & 1.6 & $\begin{array}{l}342 \\
(97.4)\end{array}$ & 88.4 & $\begin{array}{l}45 \\
(100.0)\end{array}$ & 11.6 & $\begin{array}{l}387 \\
(97.7)\end{array}$ \\
\hline No & $9(2.3)$ & 100 & $0(00.0)$ & $0(00.0)$ & $9(2.6)$ & 100.0 & $0(00.0)$ & $0(00.0)$ & $9(2.3)$ \\
\hline \multicolumn{10}{|l|}{$\begin{array}{l}\text { Access to } \\
\text { basic } \\
\text { sanitation }\end{array}$} \\
\hline Yes & $\begin{array}{l}251 \\
(64.4)\end{array}$ & 98.4 & $4(66.7)$ & 1.6 & $\begin{array}{l}224 \\
(63.8)\end{array}$ & 87.8 & $\begin{array}{l}31 \\
(68.9)\end{array}$ & 12.2 & $\begin{array}{l}255 \\
(64.4)\end{array}$ \\
\hline No & $\begin{array}{l}139 \\
(35.6)\end{array}$ & 98.6 & $2(33.3)$ & 1.4 & $\begin{array}{l}127 \\
(36.2)\end{array}$ & 90.1 & $\begin{array}{l}14 \\
(31.1)\end{array}$ & 9.9 & $\begin{array}{l}141 \\
(35.6)\end{array}$ \\
\hline Total & 390 & & 6 & & 351 & & 45 & & 396 \\
\hline
\end{tabular}

More than half of the participants (64.4\%) reported having basic sanitation at home and 141 (35.6\%) did not have (Table 2). Most of the pregnant women, 355 (89.6\%) reported lack of knowledge of the virus diseases under study, 36 (9.1\%) had hear of CMV and Rubella but they do not know anything about it and $5(1.3 \%)$ pregnant women reported knowing something about the diseases under study.

The frequency of CMV infection was higher among pregnant women in the first trimester (199; 51.0\%), followed by pregnant women in the second (152; $39.0 \%)$ and in the third trimester $(39 ; 10.0 \%)$. The frequency of CMV infection in relation to the pregnant women age was $5.9 \%(n=23)$ in the group of $\leq 19$ years, $28.2 \%(n=110)$ in the group of $20-25$ years, $51.2 \%(n=202)$ in the group of $26-35$, and $14.1 \%(n=55)$ in the group of $36-47$ years $($ Table 2$)$. The mean age of CMV positivity was $28.0 \pm 7.1$ (Mean \pm SD). Regarding the obstetric history, the frequency of CMV infection was similar in pregnant women regardless of the month of gestation and parity (number of births or miscarriages). Among the pregnant women, 173 (43.7\%) had a history of abortion and $223(56.3 \%)$ never had an miscarriage and there was no child death in the postpartum period (Table 2).

The frequency for Rubella virus was also higher among pregnant women in the first trimester $(181 ; 51.6 \%)$ followed by pregnant women in the second trimester $(135 ; 38.4 \%)$ and in the third trimester $(35 ; 10.0 \%)$ (Table 2$)$. The frequence of infection in relation to the age of pregnant women was $5.1 \%$ ( $\mathrm{n}=$ $18)$ in the group of $\leq 19$ years, $27.6 \%(n=97)$ in the group of $20-25$ years, $52.7 \%(n=185)$ in the group of $26-35$ years and $14.6 \%(n=51)$ in the group of $36-47$ years (Table 2 ). The mean age of rubella virus positivity was $28.6 \pm 6.2$ (Mean \pm SD).

We also study the frequence of hepatitis B and human immunodeficiency virus (HIV) in pregnant women and their association with Rubella and CMV virus infections. (Table 2). In relation to Hepatitis B, 269 pregnant women (67.9\%) presented a negative result and 127 (32.1\%) a positive result, of which 125 (98.4\%) had a positive result to CMV infection (122 with previous exposure and 3 an active primary infection), and 2 (1.6\%) presented susceptibility to primary CMV infection (Table 2). Also of the 127 pregnant women positive for hepatitis $\mathrm{B}, 114$ (89.8.\%) presented a positive result to Rubella virus (112 had prior exposure to the virus and 2 presented active primary infection), and 13 (28.9\%) were susceptible to primary infection. In relation to HIV, 337 (85.1\%) pregnant women had negative serology, and 59 (14.9\%) had positive results, of which 58 (98.3\%) with previous exposure to CMV, and 1 (6.7 \%) with susceptibility to CMV infection (Table 2). On the other hand, of the 59 pregnant women with HIV positive serology, 57 (96.6\%) had a positive result to rubella virus (56 with previous exposure to the virus and 1 with active virus infection), and 2 (4.4\%) with susceptibility to the infection.

The seroprevalence of Rubella infection in Angolan pregnant women according to independent categorical variables evaluated in this study are summarized in Table 3. In the bivariate logistic regression analysis, the variables of number of births (OR 2.478; Cl: 1.144-5.374), history of miscarriages 
(OR 2.062; Cl: 1.069-4.194), and spontaneous abortions occurred during the study (OR 3.048; Cl: 1.135-7.394), were considered an independent predictor of IgG seropositivity against rubella among pregnant women (Table 3). Other analyzed factors such as maternal age, gestacional age, residence, occupation, educational status, awareness of Rubella, access to basic sanitation, hepatitis B, were not associated with seropositivity on surveyed population. The multivariate logistic regression analysis (adjusted to age) confirm a significant increased risk for rubella in women without children (OR 2.673; Cl: 1.026-7.007) and suffering spontaneous abortion (OR 3.232; Cl: 1.192-7.952). 
Table 3

Binomial logistic regression models for the final analysis of risk factors associate for seropositivity of IgG anti-rubella antibodies in 396 pregnant woman in Luanda province, Angola.

\begin{tabular}{|c|c|c|c|c|}
\hline \multirow[t]{2}{*}{ Variable } & OR $(95 \%$ IC $)$ & p-value & OR $(95 \%$ IC) & p-value \\
\hline & \multicolumn{2}{|l|}{ Unadjusted } & \multicolumn{2}{|l|}{ Adjusted by age } \\
\hline \multicolumn{5}{|l|}{ Age } \\
\hline \multicolumn{5}{|l|}{$\leq 25$ years old (ref) } \\
\hline $25-29$ years old & $0.962(0.439-2.059)$ & 0.923 & & \\
\hline$\geq 30$ years old & $0.609(0.286-1.272)$ & 0.190 & & \\
\hline \multicolumn{5}{|l|}{ Education } \\
\hline Low (up to elementary school) & $0.619(0.304-1.196)$ & 0.167 & $0.615(0.300-1.197)$ & 0.166 \\
\hline \multicolumn{5}{|c|}{ High (high school or higher education) (ref) } \\
\hline \multicolumn{5}{|l|}{ Employment } \\
\hline Public administration service & $1.510(0.704-3.395)$ & 0.299 & $1.761(0.792-4.121)$ & 0.175 \\
\hline Homemakers & $1.033(0.340-2.863)$ & 0.951 & $1.102(0.361-3.079)$ & 0.856 \\
\hline Student & $1.402(0.516-3.664)$ & 0.492 & $1.064(0.368-3.001)$ & 0.905 \\
\hline \multicolumn{5}{|c|}{ Street vendor, saleslady and restaurant waitress (ref) } \\
\hline \multicolumn{5}{|l|}{ Marital status } \\
\hline \multicolumn{5}{|l|}{ Single (ref) } \\
\hline Married & $1.347(0.696-2.543)$ & 0.363 & $1.390(0.715-2.639)$ & 0.319 \\
\hline \multicolumn{5}{|l|}{ Gestational age } \\
\hline \multicolumn{5}{|l|}{ 1st trimester (ref) } \\
\hline 2nd and 3rdtrimestre & $1.346(0.722-2.536)$ & 0.351 & $1.377(0.737-2.604)$ & 0.317 \\
\hline \multicolumn{5}{|l|}{ Number of births } \\
\hline 0 & $2.478(1.144-5.374)$ & $0.0203^{*}$ & $2.673(1.026-7.007)$ & $0.0439 *$ \\
\hline 1 & $1.692(0.789-3.627)$ & 0.1724 & $1.694(0.748-3.825)$ & 0.2020 \\
\hline \multicolumn{5}{|l|}{2 or 3 (ref) } \\
\hline \multicolumn{5}{|l|}{ Children at home } \\
\hline 0 or 1 & $1.818(0.969-3.404)$ & 0.0606 & $1.689(0.840-3.394)$ & 0.139 \\
\hline \multicolumn{5}{|l|}{2 or more (ref) } \\
\hline \multicolumn{5}{|l|}{ Spontaneous abortion } \\
\hline Yes & $3.048(1.135-7.394)$ & $0.018^{\star}$ & $3.232(1.192-7.952)$ & $0.0139 *$ \\
\hline \multicolumn{5}{|l|}{ No (ref) } \\
\hline \multicolumn{5}{|l|}{ History of miscarriages } \\
\hline \multicolumn{5}{|l|}{ Yes (ref) } \\
\hline No & $2.062(1.069-4.194)$ & $0.0364^{\star}$ & $2.048(0.957-4.508)$ & 0.0676 \\
\hline \multicolumn{5}{|l|}{ Hepatitis B } \\
\hline Positive & $0.844(0.413-1.636)$ & 0.627 & $0.839(0.410-1.629)$ & 0.617 \\
\hline \multicolumn{5}{|l|}{ Negative (ref) } \\
\hline \multicolumn{5}{|l|}{ Access to basic sanitation } \\
\hline \multicolumn{5}{|l|}{ Yes (ref) } \\
\hline No & $0.892(0.452-1.697)$ & 0.735 & $0.867(0.437-1.653)$ & 0.672 \\
\hline
\end{tabular}


The geospatial distribution of pregnant women seropositive for CMV and Rubella antibodies in Luanda can be observed in Fig. 1. Based on participants' place of residence we observed a marked geographical pattern, with a high incidence density near Lucrecia Paim Maternity. The geographical distribution of pregnant women with and without antibodies to CMV and Rubella was similar, and we observed a statistically significant spatial dependency.

\section{Discussion}

The present study was performed to investigate the seroprevalence of CMV and rubella infection in pregnant women in the northern Angola city of Luanda. We found an overall seroprevalence rate for $\mathrm{CMV}$ infection of $98.5 \%$ and for Rubella infection about $88.6 \%$. This is the first study conducted in Angola to evaluate the rates of CMV and Rubella infection in pregnant women. In a general way, there is a lack of knowledge about the epidemiology of CMV and Rubella infection in Angola. In this context, we cannot compare our seroprevalence results with others in pregnant women in Angola.

CMV infection is endemic in almost all the world, occurring throughout the year without seasonal variations. The rates of seropositivity in the population vary greatly according to geographical, ethnic and socioeconomic factors. The prevalence of CMV-specific antibodies increases with age and in the less favored socioeconomic groups of developed and developing countries [12, 13]. Other known contributing factors for CMV infection including education, sexual promiscuity, and blood transfusion $[14,15]$. Also the contact with children is considered a risk factor, once the young children stands out as sources of CMV infection in pregnant women [16]

Our results of the seroprevalence of CMV antibodies in pregnant women were similar to previous studies in other African countries: 92\% in Nigeria [16], 97.5\% in Sudan [17], 96.3\% in Tunisia [18], 87\% in Gambia [19], 88.5\% in Ethiopia [20], and 86\% in Kenya [21]. Moreover, our data were also similar with results report in other world countries with values between $92.6 \%$ and $100 \%$ : Iran [22], Palestine [23], China [24], Brazil [25], Turkey [26], Nigeria [27] and Cuba [28]. In contrast, our prevalence was higher than that reported in developed countries: $42.3 \%$ in Germany [29], 46.8\% in France, 49\% in the United Kingdom [30], 54\% in Norway [31], 56.3\% in Finland [32], 58.7\% in France [33], 65.9\% in Italy [34], 66\% in Japan [35], 62.4\% in Poland [12] and 70.0\% in the United States [36].

In the present study, all women who were CMV-IgM positive were also seropositive for IgG. In most of these cases there is a need to perform IgG avidity test as an alternative to provide the status of acute infection $[37,38]$. However, in our study it was not possible define what proportion of these cases represented primary infection or reactivation because we we didn't have acess to IgG avidity test.

In USA a recent analysis of CMV IgM seroprevalence in women at reproductive age also found that $97.5 \%$ of IgM seropositive women were CMV IgG seropositive [36]. Other study performed in Pakistan, showed that $95.3 \%$ of individuals who were IgM seropositive were equally seropositive for IgG [39]. In countries with a high prevalence of CMV infection, such as Korea and Turkey, IgG avidity testing have shown that none of the women with a proflile of IgM and IgG positive had evidence of a primary infection [26,37]. As such, we could suggest that the great majority of seropositive cases in our study represent viral recurrent reinfection or reactivation rather than primary infection. The high IgG seropositivity is alarming which calls for the need to screen these women for potential active infections. Further studies on the impact of CMV on poor pregnancy outcomes are highly recommended in the developing countries [40].

The profile of CMV-IgM negative/CMV-IgG positive in pregnant women (96.5\%) indicates that the great majority of infections probably occurred during childhood or adolescence. Our results showed that all age groups are equally likely to be infected with CMV, being the prevalence high at all ages (1547 years old).

Several studies showed that low socioeconomic status was found to predict CMV IgG seropositivity [12]. The majority Angolan population is of low socioeconomic level. Although we did not have data about the socioeconomic level (through the material deprivation index; MDI) of the studied population, it should be pointed out that this study was carried out in a public maternity hospital where the majority of the attendants are women of low family income. Moreover, the majority of population in the city of Luanda reside in highly populated squatters with close contacts which favors transmission of airborne diseases. The womens participating in the present study resides in the urban area and there were no differences in CMV prevalence in relation to a specific area of residence. The high prevalence also could be explained by poor hygienic conditions that can to perpetuate the cycle of CMV transmission in the developing countries [40]. However, in the present study we not found stastically association between basic sanitation and CMV seropositivity.

In the present study, HIV infected women were more likely to be CMV IgG seropositive than HIV negative women. WHO recommends that all the pregnant women should be advise and tested for HIV at the first prenatal visit. There is a need to improve prenatal services in our setting to ensure that all women are counseled and tested for HIV.

$\mathrm{CMV}$ is a virus that has a great potential to proliferate in humans for several reasons. The infection is usually subclinical allowing that infected individuals remain active and thus maintain the possibility of transmission to other susceptible individuals. Moreover, the CMV is not eradicated from the host after the primary infection, remaining in the body for the rest of its life [13], and occasionally may be reactivated (endogenous infection). In addition, the host although infected do not acquire immunity and can undergo further infection by different strains of the virus (exogenous reinfection) [41]. Another explanation for the easy spread of CMV is that its excretion may persist for an extended period of time. For example, it is known that in the case of congenital infections, viral excretion by children may occur for years, increasing the likelihood of transmission to other individuals [42, 43]. On the other hand, some studies have observed that closed environments with many children are sites that facilitate the spread of the virus. In all these cases the transmission occurs mainly through contact with urine or saliva of infected children [44]. We analyzed the influence of the contact of pregnat women with 
children through the number of births and children at home. The women with children at home had a greater seroprevalence of CMV infection than those without children at home.

An additional finding of our study was that the majority of pregnant women with IgG and IgM positive were in the first trimester of gestation, the period of highest risk to the fetus in case of virus transmission [45]. It is reasonable to hypothesize that some infections would have been avoided had these women been informed at an earlier stage of pregnancy. Ideally, all women should be tested for CMV antibody and informed before pregnancy. Indeed, in a population of women receiving fertility treatment, preconception screening and counseling, seems to have a risk reduced to CMV infection in pregnancy [46]. Moreover, preconception testing would also reduce problems arising from the detection and interpretation of CMV-specific IgM antibody in pregnant woman $[47,48]$.

CMV stands out as the major cause of congenital infection, reaching rates between 0.2 and $2.6 \%$ of the total number of births worldwide, being responsible for cases of neonatal mortality and morbidity [49]. Fetal CMV infection occurs in approximately $40 \%$ of cases of maternal primary infection [50]. Therefore, it would be beneficial to inform pregnant women about the need for follow-up to detect prenatal infection and to plan appropriate intervention such as the use of drugs to control infection and / or prevent fetus infection [20].

The epidemiological importance of Rubella virus is related to the Congenital Rubella Syndrome (CRS) that affects the fetus or the newborn due to the infection contracted by the mother during pregnancy. The overall seroprevalence of rubella among pregnant women in the present study was $88.6 \%$. Similar results has been reported from other African countries such as Ethiopia (89\%) [51], Senegal (90.1\%) [52], Namibia (85.0\%) [53] Burkina Faso (95\%) [54] and Zimbabwe (92\%) [55]. Also in other countries of the world the prevalence is high: $88.1 \%$ and $93.5 \%$ in Turkey [56, 57]; 87\% in United States of America (USA); $98 \%$ in Spain; and $96.3 \%$ Iran [58, 59]. In contrast, the seroprevalence in this study is higher than reports from Democratic Republic of Congo (58.97\%) [60], Sudan (65\%) [61] and Nigeria (68\%) [62]. These variations might be due to the difference in the endemicity of the virus, the sample size of the studies, and the laboratory methods used.

The profile of IgM and IgG immunoglobulins is important to characterizing infection in a given area [63]. The presence of only IgM or both IgM and IgG antibodies at the same time indicates an acute/recent rubella virus infection. However, the presence of IgG antibody in the absence of IgM is a seromarker of immunity against rubella virus [64]. The absence of both $\lg M$ and $\lg G$ antibodies indicates susceptibility to acquiring rubella infection.

In the present study, both rubella-specific IgM and IgG antibodies were analyzed among pregnant women to determine acute/recent infections and the levels of immunity against rubella virus infection in Luanda, Angola. Despite the general very high seroprevalence of rubella infection, $11.4 \%$ of the pregnant woman were seronegative. The susceptibility rate in among adult women could result in outbreaks of CRS [51, 65]. Therefore, attention must be paid to the susceptible group of women in this study in order to reduce the risk of CRS in their future pregnancies.

Based on the previous recommendations of the US National Committee for Clinical Laboratory Standards (NCCLS) [66] and international agreements and guidelines [67], in the absence of IgM, the pregnant women who had rubella IgG levels $\geq 10 \mathrm{IU} / \mathrm{ml}$ were classified as immune and those with IgG levels < $10 \mathrm{IU} / \mathrm{ml}$ were classified as susceptible. In the present study, $87.6 \%$ of the pregnant women had IgG levels of $>10 \mathrm{IU} / \mathrm{ml}$ (Tabela 1$)$. None of these pregnant women had a previous history of rubella vaccination and they were immune from rubella infections. This might be due to the endemicity of the virus in the study area that sustained previous infections of the participants before conception or during their childhood, as rubella infection is common among children and teenagers in some countries $[51,68]$.

The prevalence of rubella IgG (87.6\%) in this study was greater than reported in Burkina Faso (77\%) [54], in Niger (53\%) [69] and southern India (65\%) [70]. However, the IgG positivity rate was lower than that found in studies conducted in other countries like Nigeria (97.9\%) [71], Cameroon (88.6\%) [72], Turkey (96.1\%) [73], Italy (85.8\%) [74] and Mexico (97.1\%) [75]. These variations in rubella IgG positivity in different countries might be due to the difference in the endemicity of the rubella virus and the presence or absence of rubella vaccination in their immunization programs.

In the present study, $1.0 \%$ of the total pregnant women had both rubella IgM and IgG antibodies. The rubella virus re-infection following natural immunity is very rare [51]. Therefore, the pregnant women might be in stages of primary rubella infection. Since these pregnant women were in the first and second trimester of pregnancy, they might have acquired the infection during the pregnancy and subsequently developed IgG antibodies within 30 days of infection [76]. This indicates that these pregnant women might not be immune before pregnancies and the fetuses can not be excluded from rubellaassociated risks.

Although there are no data of CRS in Angola, the newborns from women infected with rubella during early pregnancy might acquire a congenital rubella infection and be born with rubella-associated congenital anomalies or CRS. Therefore, the screening of women of child-bearing age before conception or during pregnancy might be crucial to reduce the consequences of acute rubella infection during pregnancy [51].

In the multivariate logistic regression analysis, a statistically significant association was found between rubella IgG positivity with spontaneous abortions during the study; all pregnant women who had a spontaneus abortions were seropositive for anti-rubella-lgG. The rubella was considered as an etiologic agent for miscarriages in many countries [57,77]. Therefore, more attention should placed on those pregnant women who had recent or acute infections due to the teratogenic nature of the virus [78]. Moreover, pregnant women who have a previous bad obstetric history may be more vulnerable to acquiring acute rubella infections [79]. Although the mechanism is not clear and further studies are needed, a similar finding has also been reported in other studies $[77,80]$. 
No statistically significant difference was found between anti-Rubella antibodies positivity and socio-demographic characteristics of the pregnant women. A similar finding was also reported in Namibia [53], Southern Ethiopia [81], and Nigeria [82].

All the pregnant participants in the present study live in urban settings. The high population density in urban areas might increase the contact rate and pregnant women without protective levels of rubella immunity might acquire the infections [51]. A finding was reported in the pre-vaccine era in other countries $[83,84,85]$.

To reduce the circulation of the Rubella virus, vaccination is essential and is the only way to prevent the disease [57, 86]. Rubella is commonly mistaken for other diseases because symptoms such as sore throats and headaches are common to other infections, making it difficult to diagnose [57]. Although not serious, rubella is particularly dangerous in the congenital form. In this case, it may leave irreversible sequels in the fetus as glaucoma, cataract, cardiac malformation, delayed growth, deafness and others. Therefore, prevention should be focused [86].

The WHO [65] suggests the following strategies for the prevention of Rubella: (i) Provide right to protection to school-age women and / or girls (ii) Vaccinate to provide indirect protection by reducing the transmission of rubella virus infection (iii) a combination of these approaches. The rubella vaccine was included in the Angolan national vaccination plan in April 2018 an initial stage only covered children up to 14 years of age [87].

The prevalence of CMV and Rubella infection can be attributed to low socioeconomic status and poor hygienic. Currently, about $36 \%$ of the population lives below the poverty line and with limited access to basic public services (water, sanitation, energy, health, education and housing). In the education sector, Angola is considered by UNESCO as a low educational development index country, ranking 111th out of 120 countries in the UNESCO Education for All 2012, with a value of 0.685 and a gender parity index of 0.734 [88].

There is no way to know how many cases of CMV and Rubella are identified each year in Angola. Thus, there aren't effective intervention to control CMV and Rubella infection in the country. In the case of CMV, preventive measures including changes in hygiene behavior of seronegative pregnant women should be implemmented as well as routine maternal screening for primary infection. Moreover, treatment with hyperimmune human immunoglobulin and the administration of aciclovir or its derivative valaciclovir should be considered once do not have teratogenic side effects when administered in the early stages of pregnancy $[89,90]$.

\section{Conclusion}

Overall, this study showed that there is a high seroprevalence of anti-CMV and anti -Rubella antibodies in pregnant women in Luanda. Therefore, it is important improve rapid and accurate diagnosis of CMV and Rubella infection in pregnant women to prevent major complications such as congenital infections. It would be also important to implement national screening on CMV, rubella, and other diseases linked to maternal and child health. This study showed that although most pregnant women were immune to rubella in Luanda, a considerable number are still not immune. Therefore, rubella vaccination should be offered to women with rubella-specific susceptibility to prevent further complications such as congenital infections, reduce the incidence of birth defects, and preserve maternal and child health.

\section{Abbreviations}

95\% Cl 95\% Confidence Intervals

col Cut-off índex

CRS Congenital Rubella Syndrome

ECL Electrochemiluminescence

HIV human immunodeficiency virus

LPMH Lucrécia Paim Maternity Hospital

MDI material deprivation index

NCCLS National Committee for Clinical Laboratory Standards

OR Odds Ratio

SPSS Statistical Package for the Social Sciences

TORCH Toxoplasmosis, Other (syphilis, varicella-zoster, parvovirus B19), Rubella, Cytomegalovirus and Herpes

UNESCO United Nations Educational, Scientific and Cultural Organization

WHO World Health Organization

\section{Declarations}


The present study has been approved by the Research Ethics Committee of Lucrécia Paim Maternity Hospital (LPMH) through the National Institute of Public Health of the Republic of Angola ( $n^{\circ} 301019$; S1 File). Participating individuals provided a written signed informed consent prior to sample collection and for participants younger than 18 years, informed consent was provided by parents or guardians after a detailed explanation of the objectives of the work.

\section{Consent to publish}

Not Applicable'

\section{Availability of data and materials}

Authors declare that all data are fully available without restriction.

\section{Competing Interests}

The funders had no role in study design, data collection and analysis, decision to publish, or preparation of the manuscript.

\section{Funding}

MCS, CPF: European Regional Development Fund (ERDF), through the Centro 2020 Regional Operational Programme under project CENTRO-01-0145FEDER-000008:BrainHealth 2020, and through the COMPETE 2020 - Operational Programme for Competitiveness and Internationalisation and Portuguese national funds via FCT - Fundação para a Ciência e a Tecnologia, I.P., under strategic project P0CI-01-0145-FEDER-007440 (UID/NEU/04539/2013).

ANV: Calouste Gulbenkian Foundation, Lisbon, Portugal for the PhD scholarship grant (ref. 66/SBG /18).

\section{Authors' contributions}

Conceptualization: ANV, CPF, MCS

Methodology: ANV, CPF, RA, PA, MCS

Validation: RA, PS, MCS

Resources: ANV, CPF, RA, PS, MCS

Writing (original draft preparation): ANV, CPF, RA, MCS

Writing (review and editing): RA, MCS

Supervision: MCS

Funding acquisition: MCS

\section{Acknowledgments}

Authors are kindly thankful to the medical and nursing team of the department of obstetrics of the Lucrecia Paim Maternity and to Clinical Pathology Service of Clínica Sagrada Esperança, Luanda, for collaboration throughout the survey and to the National Research Institute for Health of Angola and National Institute of Statistics of Angola.

\section{References}

1. -Numan O, Vural F, Aka N, Alpay M, Coskun AD. TORCH seroprevalence among patients attending obstetric Care Clinic of Haydarpasa Training and Research Hospital affiliated to Association of Istanbul Northern Anatolia Public Hospitals. Northern Clinics of Istanbul. North Clin Istanb. 2015;2(3):203-9.

2. -Tavares MV, Domingues AP, Tavares M, Malheiro E, Tavares F, Moura P. Citomegalovírus. There is a Place to Trace During Pregnancy? Acta Med Port. 2011;24(S4):1003-8.

3. -Schottstedt V, Blümel J, Burger R, Drosten C, Gröner A, Gürtler L, Heiden M, Hildebrandt M, Jansen B, Montag-Lessing T, Offergeld R, Pauli G, Seitz R, Schlenkrich U, Strobel J, Willkommen H. von König CH. Human Cytomegalovirus (HCMV) - Revised. Transfus Med Hemother. 2010;37(6):365-75.

4. -Benoist G, Jacquemard F, Leruez -Ville M, Ville Y. Cytomegalovirus (CMV) congenital infection. Gynecol Obstet Fertil. 2008;36(3):248-60.

5. -Gumbo H, Chasekwa B, Church JA, Ntozini R, Mutasa K, Humphrey JH, Prendergast AJ. Congenital and postnatal CMV and EBV acquisition in HIVinfected Zimbabwean infants. PLoS One. 2014 Dec 18; 9(12):e114870.

6. -Griffin DE, Alphaviruses. in Fields virology DM, Knipe, Howley PM, editors, Editors. Lippincott Williams \& Wilkins: Philadelphia, PA. 2013 ; p. $651-686$.

7. -Banatvala JE, Brown DW. Rubella. Lancet. 2004;363(9415):1127-37. 
8. -Gregg NM. Congenital Cataract Following German Measles in the Mother. Trans Ophthalmol Soc Aust. 1941;3:35-46.

9. -Ojala P, Vesikari T, Elo O. Rubella during pregnancy as a cause of congenital hearing loss. Am J Epidemiol. 1973;98:395-401.

10. -Best JM. Rubella Seminars in Fetal Neonatal Medicine. 2007;12(3):182-92.

11. -Bouthry E, Picone O, Hamdi G, Grangeot-Keros L, Ayoubi JM, Vauloup-Fellous C. Rubella and pregnancy: diagnosis, management and outcomes. Prenat Diagn. 2014;34(13):1246-53.

12. -Wujcicka W, Gaj Z, Wilczyński J, Sobala W, Spiewak E, Nowakowska D. Impact of socioeconomic risk factors on the seroprevalence of cytomegalovirus infections in a cohort of pregnant Polish women between 2010 and 2011. Eur J Clin Microbiol Infect Dis. 2014;33(11):1951-8.

13. -Cannon MJ, Schmid DS, Hyde TB. Review of cytomegalovirus seroprevalence and demographic characteristics associated with infection. Rev Med Virol. 2010;20(4):202-13.

14. -Ziemann M, Hennig H. Prevention of Transfusion-Transmitted Cytomegalovirus Infections: Which is the Optimal Strategy? Transfus Med Hemother. 2014;41(1):40-4.

15. -Foxworth MK, Wilms IR, Brookman RR, Crewe S, Adler SP. Prevalence of CMV infection among sexually active adolescents: a matched case-control study. Adolesc Health Med Ther. 2014;5:73-8.

16. -Ephraim OE, Oyinlola O, Patrick VL, Joseph UO, Charles JE. Seroprevalence and risk factors for cytomegalovirus infection among pregnant women in southern Nigeria. JMID. 2013;3(3):123-7.

17. -Khairi SI, Intisar KS, Enan KH, Ishag MY, Baraa AM, Ali YH. Seroprevalence of cytomegalovirus infection among pregnant women at Omdurman Maternity Hospital, Sudan. J Med Lab Diagn. 2013;4(4):45-9.

18. -Hannachi N, Marzouk M, Harrabi I, Ferjani A, Ksouri Z, Ghannem H, Khairi H, Hidar S, Boukadida J. [Seroprevalence of rubella virus, varicella zoster virus, cytomegalovirus and parvovirus B19 among pregnant women in the Sousse region, Tunisia]. Bull Soc Pathol Exot. 2011;104(1):62-7.

19. -Bello C, Whittle H. Cytomegalovirus infection in Gambian mothers and their babies. J Clin Pathol. 1991;44(5):366-9.

20. -Yeshwondm M, Balkachew N, Delayehu B, Mekonen G. Seroepidemiology Study of Cytomegalovirus and Rubella among Pregnant Women at St. Paul's Hospital Millennium Medical College, Addis Ababa, Ethiopia. Ethiop J Health Sci. 2016;26(5):427-38.

21. -Nisbet Al, Omuse G, Revathi G, Adam RD. Seroprevalence data at a private teaching hospital in Kenya: An examination of Toxoplasma gondii, cytomegalovirus, rubella, hepatitis A, and Entamoeba histolytica. PLoS One. 2018;13(10):e0204867.

22. -Erfanianahmadpoor M, Nasiri R, Vakili R, Hassannia T. Seroprevalence, transmission, and associated factors of specific antibodies against cytomegalovirus among pregnant women and their infants in a regional study. Saudi Med J. 2014;35(4):360-4.

23. -Neirukh T, Qaisi A, Saleh N, Rmaileh AA, Zahriyeh EA, Qurei L, Dajani F, Nusseibeh T, Khamash H, Baraghithi S, Azzeh M. Seroprevalence of cytomegalovirus among pregnant women and hospitalized children in Palestine. BMC Infect Dis. 2013;13:528.

24. -Zhang S, Hu L, Chen J, Xu B, Zhou Yi-Hua, Hu Y. Cytomegalovirus Seroprevalence in Pregnant Women and Association with Adverse Pregnancy/Neonatal Outcomes in Jiangsu Province, China. PLoS One. 2014;9(9):e107645.

25. -Yamamoto AY, Castellucci RA, Aragon DC, Mussi-Pinhata MM. Early high CMV seroprevalence in pregnant women from a population with a high rate of congenital infection. Epidemiol Infect. 2013;141:2187-91.

26. -Uysal A, Taner CE, Cüce M, Atalay S, Göl B, Köse S, Uysal F. Cytomegalovirus and rubella seroprevalence in pregnant women in Izmir/Turkey: followup and results of pregnancy outcome. Arch Gynecol Obstet. 2012;286:605-8.

27. -Akinbami AA, Rabiu KA, Adewunmi AA, Wright KO, Dosunmu AO, Adeyemo TA, Adediran A, Osunkalu VO. Seroprevalence of cytomegalovirus antibodies amongst normal pregnant women in Nigeria. Int J Womens Health. 2011;3:423-8.

28. -Festary A, Kourí V, Correa CB, Verdasquera D, Roig T, Couret MP. Cytomegalovirus and herpes simplex infections in mothers and newborns in a Havana maternity hospital. MEDICC Rev. 2015;17(1):29-34.

29. -Enders G, Daiminger A, Lindemann L, Knotek F, Bäder U, Exler S, Enders M. Cytomegalovirus (CMV) seroprevalence in pregnant women, bone marrow donors and adolescents in Germany, 1996-2010. Med Microbiol Immunol. 2012;201:303-9.

30. -Pembrey L, Raynor P, Griffiths P, Chaytor S, Wright J, Hall AJ. Seroprevalence of cytomegalovirus, Epstein Barr virus and varicella zoster virus among pregnant women in Bradford: a cohort study. PLoS One. 2013;8:e81881.

31. -Barlinn R, Dudman SG, Trogstad L, Gibory M, Muller F, Magnus P, Rollag H. Maternal and congenital cytomegalovirus infections in a population-based pregnancy cohort study. APMIS. 2018;126(12):899-906.

32. -Alanen A, Kahala K, Vahlberg T, Koskela P, Vainionpää R. Seroprevalence, incidence of prenatal infections and reliability of maternal history of varicella zoster virus, cytomegalovirus, herpes simplex virus and parvovirus B19 infection in South-Western Finland. BJOG. 2005;112(1):50-6.

33. -Leruez-Ville M, Sellier Y, Salomon LJ, Stirnemann JJ, Jacquemard F, Ville Y. Prediction of fetal infection in cases with cytomegalovirus immunoglobulin M in the first trimester of pregnancy: a retrospective cohort. Clin Infect Dis. 2013 May;56(10):1428-35.

34. -Picone OC, Vauloup F, Cordier AGI, Parent DuC, Senat MV, Frydman R, et al. A 2-year study on cytomegalovirus infection during pregnancy in a French hospital. Br J Obstet Gynecol. 2009;116(6):818-23.

35. -Ikuta K, Minematsu T, Inoue N, Kubo T, Asano K, Ishibashi K, Imamura T, Nakai H, Yoshikawa T, Moriuchi H, Fujiwara S, Koyano S, Suzutani T. Cytomegalovirus (CMV) glycoprotein H-based serological analysis in Japanese healthy pregnant women, and in neonates with congenital CMV infection and their mothers. J Clin Virol. 2013;58(2):474-8. 
36. -Wang C, Sheila C. Dollard MM, Amin, Stephanie R. Bialek Cytomegalovirus IgM Seroprevalence among Women of Reproductive Age in the United States. PLoS One. 2016;11(3):e0151996.

37. -Seo S, Cho Y, Park J. Serologic screening of pregnant Korean women for primary human cytomegalovirus infection using IgG avidity test. Korean J Lab Med. 2009;29(6):557-62.

38. -Lazzarotto T, Varani S, Spezzacatena P, Gabrielli L, Pradelli P, Guerra B, Landini MP. Maternal IgG avidity and IgM detected by blot as diagnostic tools to identify pregnant women at risk of transmitting cytomegalovirus. Viral Immunol. 2000;13(1):137-41.

39. -Ibrahim S, Siddiqui AA, Siddiqui AR, Ahmed W, Moss PA, Lalani EM. Sociodemographic factors associated with IgG and IgM seroprevalence for human cytomegalovirus infection in adult populations of Pakistan: a seroprevalence survey. BMC Public Health. 2016;16:1112.

40. -Chibwe E, Mirambo MM, Kihunrwa A, Mshana SE. Magnitude of the Cytomegalovirus infection among pregnant women attending antenatal clinics in the city of Mwanza, Tanzania. BMC Res Notes. 2017 Sep;20(1):489. 10(.

41. -Yamamoto AY, Mussi-Pinhata MM, Boppana SB, Novak Z, Wagatsuma VM, Oliveira PF, Duarte G, Britt WJ. Human cytomegalovirus reinfection is associated with intrauterine transmission in a highly cytomegalovirus-immune maternal population. Am J Obstet Gynecol. 2010;202:297.

42. -Strauss JH, E. G. Strauss. Viruses and Human Disease. Second Edition, 2008; Elsevier Academic Press, New York.

43. -Centers for Disease Control (CDC). Prevalence of cytomegalovirus excretion from children in five day-care centers-Alabama. MMWR Morb Mortal Wkly Rep. 1985;34(4):49-51.

44. -Hantz S, Alain S. [Cytomegalovirus infections]. Rev Prat. 2019;69(3):301-6.

45. -Davis NL, King CC, Kourtis AP. Cytomegalovirus infection in pregnancy. Birth Defects Res. 2017;109(5):336-46.

46. -Reichman O, Miskin I, Sharoni L. Preconception screening for cytomegalovirus: an effective preventive approach. BioMed Res. Int. $2014: 135416$.

47. -Guerra B, Simonazzi G, Lazzarotto T. Impact of diagnostic and confirmatory tests and prenatal counseling on the rate of pregnancy termination among women with positive cytomegalovirus immunoglobulin M antibody titers. Am. J. Obstet. Gynecol. 2007;196(3) (221.e1-221.e6).

48. -Revello MG, Gerna G. Diagnosis and management of human cytomegalovirus infection in the mother, fetus, and newborn infant. Clin Microbiol Rev. 2002;15:680-715.

49. -Korndewal MJ, Oudesluys-Murphy AM, Kroes ACM, et al. Congenital Cytomegalovirus Infection: Child Development, Quality of Life and Impact on Daily Life. Pediatr Infect Dis J. 2017;36(12):1141-7.

50. -Carlson A, Norwitz ER, Stiller RJ, Cytomegalovirus Infection in Pregnancy: Should All Women Be Screened? Rev Obstet Gynecol. 2010 Fall; 3(4): 172179.

51. -Wondimeneh $\mathrm{Y}$, Tiruneh $\mathrm{M}$, Ferede $\mathrm{G}$, Abera B, Workineh $\mathrm{M}$, Birhanie $\mathrm{M}$, Tessema B. Rubella virus infections and immune status among pregnant women before the introduction of rubella vaccine in Amhara Regional State, Ethiopia. Int J Infect Dis. 2018;76:14-22.

52. -Dromigny JA, Nabeth P. Perrier Gros Claude JD.Evaluation of the seroprevalence of rubella in the region of Dakar (Senegal). Trop Med Int Health. 2003;8(8):740-3.

53. -Jonas A, Cardemil CV, Beukes A, Anderson R, Rota PA, Bankamp B, Gary HE Jr, Sawadogo S, Patel SV, Zeko S, Muroua C, Gaeb E, Wannemuehler K, Gerber S, Goodson JL. Rubella immunity among pregnant women aged 15-44 years, Namibia, 2010. Int J Infect Dis. 2016;49:196-201.

54. -Tahita MC, Hübschen JM, Tarnagda Z, Ernest D, Charpentier E, Kremer JR, Muller CP. Ouedraogo JB.Rubella seroprevalence among pregnant women in Burkina Faso. BMC Infect Dis. 2013;13:164.

55. -Mamvura TS, Chin'ombe N, Ruhanya V, Nziramasanga P. Seroprevalence of rubella virus IgG in pregnant women in Harare, Zimbabwe. Germs. 2015;5(2):50-2.

56. -Aksakal FN, Maral I, Cirak MY, Aygun R. Rubella seroprevalence among women of childbearing age residing in a rural region: is there a need for rubella vaccination in Turkey Jpn. J Infect Dis. 2007;60:157-60.

57. -Jahromi AS, Kazemi A, Manshoori G, Madani A, Moosavy SH, Seddigh B. Seroprevalence of Rubella virüs in women with spontaneus abortion. Am J Inf Dis. 2011;7:16-9.

58. -Karabulut A, Polat Y, Türk M, Isik Balci Y. Evaluation of rubella, toxoplasma gondii and cytomegalo virus seroprevalemces among pregnant women in Denizli province. Turk J Med Sci. 2011;41:159-64.

59. -Remington JS, McLeod R, Wilson CB, Desmonts G. Toxoplasmosis. In: Remington JS, Klein JO, Wilson CB, Nizet V, Maldonado YA, editors. Infectious Diseases of the Fetus and Newborn Infant. 7th ed. Philadelphia: Elsevier-Saunders; 2011. pp. 918-1041.

60. -Zanga J, Mbanzulu MK, Kabasele AF, Ngatu NR, Wumba DR. Rubella Seroprevalence and real-time PCR detection of RUBV among Congolese pregnant women. BMC Infect Dis. 2017;17(1):250.

61. -Hamdan H, Abdelbagi IE, Nasser NM, Adam I. Seroprevalence of cytomegalovirus and rubella among pregnant women in western Sudan. Virol J. 2011;8:217.

62. -Bamgboye AE, Afolabi KA, Esumeh FI, Enweani IB. Prevalence of rubella antibody in pregnant women in Ibadan, Nigeria. West Afr J Med. 2004;23(3):245-8.

63. -Olajide OM, Aminu M, Randawa AJ, Adejo DS. Seroprevalence of rubella-specific IgM and IgG antibodies among pregnant women seen in a tertiary hospital in Nigeria. Int J Womens Health. 2015;7:75-83.

64. -Mirambo MM, Mushi MF, Seugendo M, Majigo M, Groß U, Mshana SE. Serological evidence of acute rubella infection among under-fives in Mwanza: a threat to increasing rates of congenital rubella syndrome in Tanzania. Ital J Pediatr. 2016;42:54.

Page $15 / 17$ 
65. -WHO. Rubella vaccines WHO position paper. Wkly Epidemiol Rec. 2011;86:301-16.

66. -Skendzel LP. Rubella immunity: defining the level of protective antibody. Am J Clin Pathol. 1996;106:170-4.

67. -Dimech W, Panagiotopoulos L, Francis B, Laven N, Marler J, Dickeson D, et al. Evaluation of eight anti-rubella virus immunoglobulin g immunoassays that report results in international units per millilitre. J Clin Microbiol. 2008;46:1955-60.

68. Dejenie -Shiferaw, Teklu B, Teshome E, Assefa A, BekeleHiwot K, Berhane B. The epidemiology of laboratory confirmed rubella cases in Oromia Region, Ethiopia, 2010-2015: data from the measles case-based surveillance system. Am J Clin Pathol. 2016;146:227.

69. -Onakewhor JU, Chiwuzie J. Seroprevalence survey of rubella infection in pregnancy at the University of Benin Teaching Hospital, Benin City, Nigeria. Niger J Clin Pract. 2011;14:140-5.

70. -Padmaja M, Radhakrishna PM, Varghese SJ. Seroprevalence of immunity to rubella in pregnant women. Natl Med J India. 2010;23:248-9.

71. -Mohammed DA, Shittu O, Sadauki H, Olayinka A, Kolawole B, Adejo D. Prevalence of rubella IgG antibodies among pregnant women in Zaria, Nigeria. Int Health. 2010;2:156-9.

72. -Fokunang CN, Chia J, Ndumbe P, Mbu P, Atashili J. Clinical studies on seroprevalence of rubella virus in pregnant women of Cameroon regions. Afr J Clin Exp Microbiol. 2010;11:79-94.

73. -Tamer GS, Dundar D, Caliskan E. Seroprevalence of Toxoplasma gondii, rubella and cytomegalovirus among pregnant women in western region of Turkey. Clin Invest Med. 2008;32:E43-7.

74. - Calimeri CA, Fauci VLA, Squeri R, Grillo OC, Lo Giudice D. Prevalence of serum anti-rubella virus antibodies among pregnant women in southern Italy. Int J Gynecol Obstet. 2012;116:211-3.

75. -Alvarado-Esquivel C, Hernández-Tinoco J, Sánchez-Anguiano LF, Ramos-Nevárez A, Cerrillo-Soto SM, Estrada-Martínez S, Martínez-Ramírez L, PérezÁlamos AR, Guido-Arreola CA. Seroepidemiology of cytomegalovirus infection in pregnant women in Durango City, Mexico. BMC Infect Dis. 2014;14:484.

76. -Navigator ClinLab. Rubella. 2013 (Available from: http://www.clinlabnavigator.com/rubella.html.

77. -Abdolreza S, Jahromi. Akbar, Kazemi, Gita, Manshoori, Abdolhossien, Madani, Seyed-Hamid, Moosavy, and Bita, Seddigh. Seroprevalence of rubella virus in women with spontaneous abortion. Am J Infect Dis. 2011;7:16-9.

78. -Lee JY, Bowden DS. Rubella virus replication and links to teratogenicity. Clin Microbiol Rev. 2000;13:571-87.

79. -Priyanka D, Ganesh Anupriya V, Uma A, A., and Kalamani SM. Seroprevalence of rubella among asymptomatic pregnant women in a rural teaching hospital. Int J Med Microbiol Res. 2017;1:7-12.

80. -Noor, Al- Huda Ali AH, Saeed, Liqaa J, Ibraheem. Areej, Abbas Zabbon, and Enas, Waleed Shakir. Seroprevalence study of rubella virus infection among bad obstetric history and primigravida pregnant women in Iraq. World J Pharmaceut Res. 2015;4:378-84.

81. -Tamirat B, Hussen, Techalew, and Shimelis S. Rubella virus infection and associated factors among pregnant women attending the antenatal care clinics of public hospitals in Hawassa City, Southern Ethiopia: a crosssectional study. BMJ Open. 2017;7:1-8.

82. -Pennap GR, Egwa MA. Prevalence of rubella virus infection among pregnant women accessing antenatal clinic at federal medical centre, Keffi, Nigeria. Int J Curr Microb. 2016;5:171-8.

83. -Goodson JL, Masresha B, Dosseh A, Byabamazima C, Nshimirimana D, Cochi S, Reef S. Rubella epidemiology in Africa in the prevaccine era, 20022009. J Infect Dis. 2011;204(Suppl 1):215-25.

84. -Assaad F, Ljungars-Esteves K. Rubella-world impact. Rev Infect Dis. 1985;7(Suppl 1):29-36.

85. -Hinman AR, Hersh BS, de Quadros CA. Rational use of rubella vaccine for prevention of congenital rubella syndrome in the Americas. Rev Panam Salud Publica. 1998;4(3):156-60.

86. -Avila Moura A, Mello MJG, Correia JB. Serological statuses of pregnant women in an urban Brazilian population before and after the 2008 rubella immunization campaign. Vaccine. 2016;34(4):445-50.

87. -WHO. Global measles and rubella strategic plan: 2012-2020 World Health Organization. 2012, pp. 1-44.

88. -World Health Organization - Angola. 2015-2019; 2015; WHO Cooperation Strategy.

89. -Adler SP, Nigro G, Pereira L. Recent advances in the prevention and treatment of congenital cytomegalovirus infections. Semin Perinatol. 2007;31:108.

90. -Kimberlin DW, Lin CY, Sánchez PJ, et al. National Institute of Allergy and Infectious Diseases Collaborative Antiviral Study Group, authors. Effect of ganciclovir therapy on hearing in symptomatic congenital cytomegalovirus disease involving the central nervous system: a randomized, controlled trial. J Pediatr. 2003;143:16-25.

\section{Figures}


(A) Pregnant women surveyed

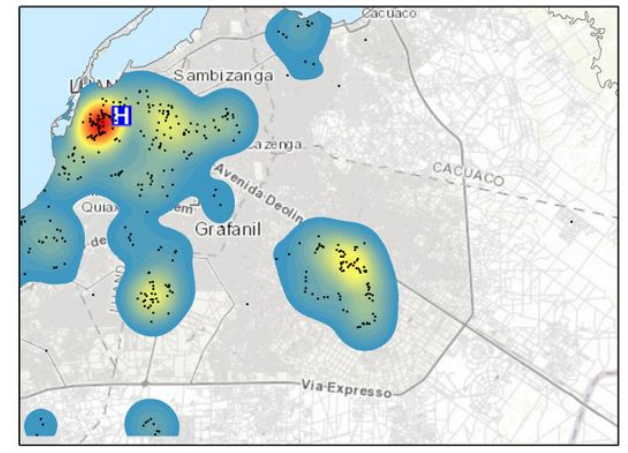

(C) Non-immune to Rubella

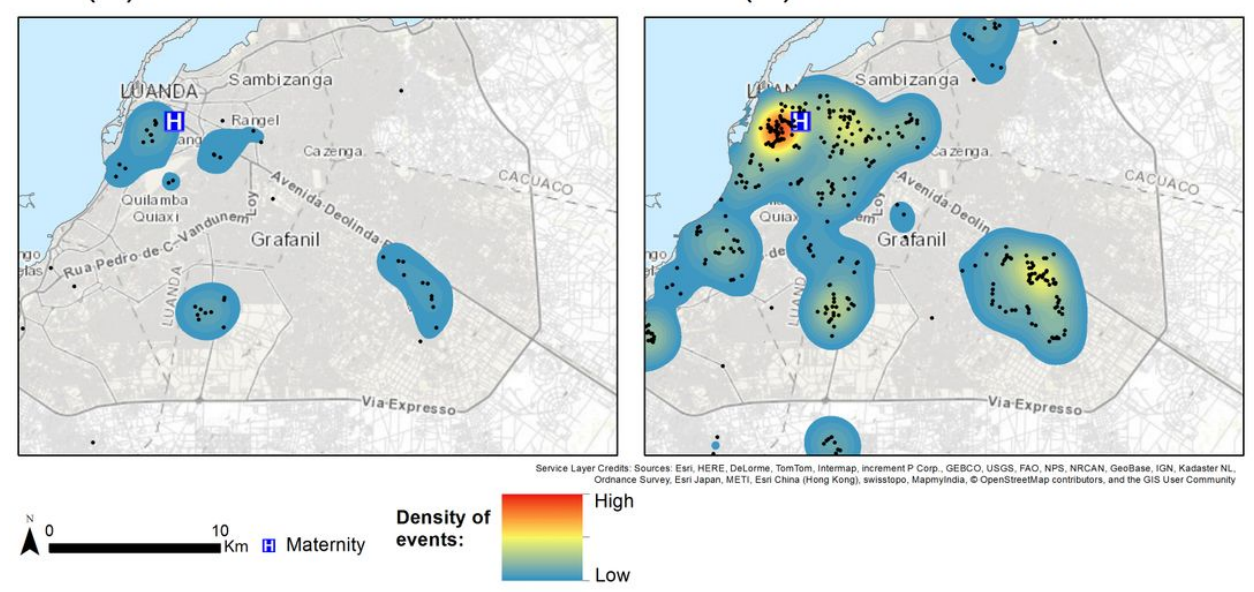

(B) Previous exposure to CMV

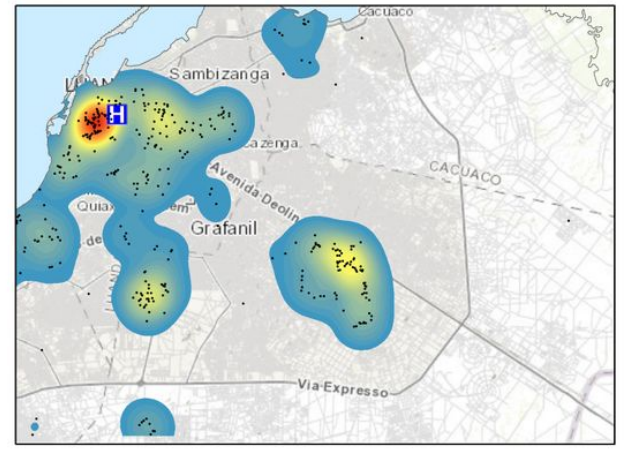

(D) Immune to Rubella

Figure 1

Geographical distribution and Gaussian kernel density surface map of pregnant women (A) with anti-CMV antibodies (B), non-immune to Rubella virus (C) and immune to Rubella virus (D) in Luanda, Angola. Note: The designations employed and the presentation of the material on this map do not imply the expression of any opinion whatsoever on the part of Research Square concerning the legal status of any country, territory, city or area or of its authorities, or concerning the delimitation of its frontiers or boundaries. This map has been provided by the authors.

\section{Supplementary Files}

This is a list of supplementary files associated with this preprint. Click to download.

- S1File.pdf

- S2File.pdf 